J. Product. \& Dev., 26(3):463-478(2021)

\title{
ANALYSIS OF GENETIC CORRELATION BETWEEN SOME TRAITS IN M WHEAT MUTANT AS INFLUENCED BY SODIUM AZIDE UNDER WATER STRESS
}

\author{
R.F Nada ; E. E. Hassan ${ }^{1}$; A.A. Hassan ${ }^{1}$ and Z.M.A. Attia ${ }^{2}$ \\ 1-Department of Plant Production Faculty of Technology and Development, \\ Zagazig University Egypt. \\ 2- Plant Research Department, Nuclear Research Center, Inshas, El-Sharkyia \\ Governorate, Egypt.
}

\section{ABSTRACT}

Correlation is the simultaneous variation of two variables. It is often desirable to observe and measure the relationship between two traits. A field experiment was conducted during the growing season $2018 / 2019$, to calculate correlation for days to heading, plant growth, spike traits, yield and its components in four wheat genotypes (Gemmeiza-11, Sids-12, Shandweel-1 and Sahel-1) in $M_{2}$ generation using sodium azaide at (0, 0.04, 0.06 and $0.08 \%)$, at the Experimental farm, Faculty of Technology and Development, Zagazig University, Egypt. This research was conducted with three replications in split plot design. Analysis of variance showed significant and highly significant differences among treatments for all traits. Mean square du to genotypes was significant and highly significant for days to 50\% heading, plant height, number of tillers/plant, peduncle length, spike length, number of spikes /plant, number of spikelets / spike, number of grains/ spike, 1000grain weight, and grain yield/plant. Meanwhile, analysis of variance for sodium azide treatments revealed highly significant for days to heading, peduncle length, No. of tillers / plant, Protein content \% and grain yield plant. While it showed significant for No. of spikeliets /spike, No. of infertile spikelets / spike, No. of fertile spikelets / spike, No. of spikes / plant, straw yield / plant and biological yield/plant.

The results demonstrated significantly $(P \leq 0.05)$ positive association between various traits, such as 1000-grain weight made positive and significant correlation with harvest index \% (0.71**) and grain yield /plant (0.62**). Straw yield/plant demonstrated positive and highly significant association with biological yield/plant (0.99**), grain yield/plant (0.83**). Meanwhile, biological yield/plant demonstrated positive and highly significant association with grain yield/plant (0.89**). Harvest index showed positive and highly significant 
association with grain yield/plant (0.72**). These results demonstrating a comprehensive selection for these traits will ultimately improve grain yield in bread wheat genotypes

Conclusively, genetic correlation coefficient represents the degree to which respective traits are correlated therefore correlation coefficient have predictive value in selection for water stress.

Key words: Analysis of Genetic Correlation, traits in $\mathrm{M}_{2}$ wheat, Mutant, Sodium Azide, Water Stress

\section{INTRODUCTION}

Bread wheat (Triticum aestivum L.) is an important source of staple food and is widely cultivated worldwide because of its good nutritional and technical properties. Improvement in wheat plants is required due to limited genetic resources of tropical wheat. In vitro strategy, mutation and selection can help genetic variation obtain genetic diversity. The breeding combination has been proven to make induction and selection of mutation more effective and efficient (Maluszynski et al. 1995). In vitro mutation technique is essential in inducing mutants, making it very important in wheat for breeding programs for increasing drought tolerance.

Sodium azide $\left(\mathrm{NaN}_{3}\right)$ is a chemical mutagen and has been one of the most powerful mutagens in crop plants. It has been reported that sodium azide affects plant physiology and decrease cyanide resistant respiration in tobacco callus (Wen and Liang, 1995). Wannajindaporn et al., (2014) reported that 28 Dendrobium mutants were generated after exposure to $\mathrm{NaN}_{3}$ under in vitro conditions.

Sodium azide creates point mutation in the genome of plants through metabolite and thus produced protein in mutant plants has different function compared to the normal plants. The mutant plants produced by the treatment of sodium azide are capable to survive under various adverse conditions and have improved yields, increased stress tolerance, longer shelf life and reduced agronomic input in comparison to normal plants reported bay Dubey et. al., (2017). Water stress is the most significant environmental stress in agriculture worldwide and improving yield under drought is a major goal of plant breeding (Cattivelli et al.,2008).

Correlation is the simultaneous variation of two variables. Correlation coefficient represents the degree to which respective traits are correlated therefore correlation coefficient have predictive value in selection. It is often desirable to observe and measure the relationship between two traits. Correlation shows that increase in a single traits cause simultaneous increase in 
the other. On the other hand correlation reflects the increase in one character is associated with a decrease in the other (Bhutto et al., 2005). Mohammad et al., (2008) reported that the relationship among yield increasing components influence on the grain yield direct or indirect way of bread wheat. Dabi et. al., (2016), reported that days to $50 \%$ heading, days to maturity, grain-filling period, spike length, and number of spikelets/ spike were non-significant positive correlation with grain yield. Ayer et al., (2017), found that plant height, 1000-grain weight, biomass yield, and harvest index\% showed positive significant correlation with grain yield in their simple correlation analysis in wheat genotypes. Ganno et. al., (2017) found that the grain yield had positive significant correlation with plant height, 1000-grain weight, biomass yield, and harvest index \% both at genotypic and non-significant positive correlations were observed between grain yield with spike length, and number of grains / spike at both genotypic. On the other hand, grain yield showed non-significant negative correlation with days to heading and number of spikelets/ spike.

Ahmad et al., (2018) reported that grain yield /plant was highly significant positive associations with biological yield /plant, number of spikelets /spike and spike length at genotypic level. Baye et al., (2020) evaluated the association of yield and its components traits and determine the direct and indirect effects of yield-related traits on grain yield. The result of analysis of variance showed significant differences among the tested genotypes for the majority of characters under study for both locations. This indicates the presence of high variability among the tested bread wheat lines. Grain yield had significant positive correlation with plant height, grains/spike, thousand grain weight, biomass yield, and harvest index\% at both genotypic including spike length and with plant height, thousand grain weight/gm., biomass yield and harvest index.

The current study was performed to estimate mean square and determine the between grain yield and its relevant traits in $\mathrm{M}_{2}$ generation of bread wheat.

\section{MATERIALS AND METHODS}

A field experiment was conducted during the growing season 2018/2019, to calculate mean square, mean performance and correlation for days to heading, plant growth, spike traits, yield and its components in four wheat cultivars i.e (Gemmeiza-11, Sids-12, Shandweel-1 and Sahel-1) in M2 generation under water stress. The seeds of all wheat cultivars were soaked in a solution of sodium azide four concentrations as follows at $(0,0.04,0.06$ and $0.08 \%$ ), for 8 hours. At the Experimental farm, Faculty of Technology and Development, Zagazig University, Egypt. This research was conducted with 
three replications in split plot design, cultivars were in the min plot and treatments in sub plot. on 17 November, in plots for obtaining M2 generation. Each plot contains 10 rows each row was 3 meter length and $25 \mathrm{~cm}$ in width, spaces between plants were $10 \mathrm{~cm}$. water stress treatment it was irrigated immediately after sowing and first irrigation was after 45 days for sowing and second irrigation up to flowering stage.

Four genotypes of bread wheat involved in the present study were obtained from Agricultural Research Center, Giza, Egypt, Name, pedigree and origin of these genotypes are presented in Table (1). Physical and chemical analyses of soil experimental were given in Table (2).

Table (1): Name, pedigree and origin of the four parental bread wheat genotypes.

\begin{tabular}{|l|l|c|}
\hline \multicolumn{1}{|c|}{ Genotypes } & \multicolumn{1}{|c|}{ Pedigree } & Origin \\
\hline $\begin{array}{l}\text { Gemmieza- } \\
11\end{array}$ & $\begin{array}{l}\text { Bow"s"/Kvz"s"//7c/seri82/3/ Giza 168/Sakha61GM7892-2GM-1GM- } \\
\text { 2GM-1GM-OGM }\end{array}$ & Egypt \\
\hline Sids- 12 & $\begin{array}{l}\text { BUC//7C/ALD/5/MAYA74/ON//1160147/3/BB/GLL/4/HAT "S } \\
\text { "/S/MAYA }\end{array}$ & Egypt \\
\hline Sahel-1 & $\begin{array}{l}\text {-VUL//CMH74A.630/4*SX.SD7096-4SD-1SD-1SD-OSD } \\
\text { N.S.732/pim/Vee"s" CR735-4SD-1SD-1SD-OSD }\end{array}$ & Egypt \\
\hline $\begin{array}{l}\text { Shandawell- } \\
1\end{array}$ & \begin{tabular}{l} 
Site/Mo/4/NACLTh.Ac//3*Pvn/3/Mirlo/Buc. CMss \\
\hline
\end{tabular} & Egypt \\
\hline
\end{tabular}

Source: Wheat Research Section, Field Crops Research Institute, Agricultural Research Center (ARC), Giza, Egypt.

Table (2): Soil mechanical and chemical analyses* of the experimental site at $30 \mathrm{~cm}$ soil depth.

\begin{tabular}{|l|l|}
\hline Soil properties & \\
\hline Mechanical analysis : & \\
Sand (\%) & 17.6 \\
Silt (\%) & 21.5 \\
Clay (\%) & 60.9 \\
Soil texture & Clay \\
\hline Chemical analysis : & 7.85 \\
PH & $98.1+-7.2$ \\
EC mmhose /cm & $1.1+-0.1 \mathrm{ppm}$ \\
Total N (ppm) & $19.12+-0.55 \mathrm{ppm}$ \\
Available P (ppm) & $350 \mathrm{pm}$ \\
Available K (ppm) & \\
& \\
\hline
\end{tabular}


The following data were recorded on ten plants: Number of days to $50 \%$ heading, plant height $(\mathrm{cm}$.$) , number of tillers / plant, peduncle length$ (cm.), spike length $(\mathrm{cm}$.), number of spikelets / spike, number of infertile spikelets / spike and number of fertile spikelets / spike, number of spikes/plant, number of grains / spike, spike grain weight (g.), 1000-grain weight (g.), grain yield/plant (g.), straw yield /plant (g.), biological yield/plant and harvest index.

\section{Statistical analysis:-}

Data were statistically analyzed using spilt plot design in $\mathrm{M}_{2}$ generation with three replication. Data were statically analyzed, and mean values were compared by using the least significant test (L. S. D) at 5\% level (Steel et. al., 1997). Correlation coefficients were calculated between pairs of studied traits for wheat cultivars and sodium azide treatments according to Singh and Narayanan (2000).

\section{RESULTS AND DISCUSSION}

Analysis of variance in $M_{2}$ generation as influenced by sodium azide:

The analysis of variance for days to $50 \%$ heading, plant height $(\mathrm{cm}$.), number of tillers/plant, peduncle length $(\mathrm{cm}$.$) , spike length (\mathrm{cm}$.$) ,number of$ spikes /plant, number of spikelets / spike, number of grains/ spike, spike grain weight (g), 1000-grain weight (g.), grain yield /plant, straw yield / plant, biological yield / plant and harvest index $\%$ in $\mathrm{M}_{2}$ generation was separately analyzed and presented in Tables (3 and 4)

The analysis of variance showed significant and highly significant differences among treatments for all traits under study except the No. of spikelets /spike, 1000-grain weight (g.) and harvest index \% which were nonsignificant. These results are harmony with those obtained by Ahmad et al., (2018) and Baye et al., (2020)

While analysis of variance between genotypes showed significant and highly significant for days to $50 \%$ heading, plant height $(\mathrm{cm}$.), number of tillers/plant, peduncle length $(\mathrm{cm}$.$) , spike length (\mathrm{cm}$.$) , number of spikes /plant,$ number of spikelets / spike, number of grains/ spike, spike grain weight (g), 1000-grain weight (g.), and grain yield /plant, but non-significant for straw yield/plant(g.), biological yield plant (g.) and harvest index \% . These results are harmony with those obtained by Baye et al., (2020). Meanwhile, analysis of variance for sodium azide treatments revealed highly significant for days to heading, peduncle length, No. of tillers / plant and grain yield plant. While it showed significant for No. of spikeliets /spike, No. of infertile spikelets / spike, 
Table (3). Mean square of Days to heading, plant growth and spike characters in four bread wheat genotypes and four different sodium azide treatments.

\begin{tabular}{|l|c|c|c|c|c|c|c|}
\hline S. V & d. f & $\begin{array}{c}\text { Days to } \\
\text { heading }\end{array}$ & $\begin{array}{c}\text { Plant } \\
\text { height } \\
\text { (cm) }\end{array}$ & $\begin{array}{c}\text { Peduncle } \\
\text { length } \\
\text { (cm) }\end{array}$ & $\begin{array}{c}\text { No. of } \\
\text { tillers/ } \\
\text { plant }\end{array}$ & $\begin{array}{c}\text { Spike } \\
\text { length } \\
\text { (cm) }\end{array}$ & $\begin{array}{c}\text { No. of } \\
\text { spikeliets } \\
\text { /spike }\end{array}$ \\
\hline Replication & 2 & 3.35 & 10.9 & 5.34 & 1.35 & 0.61 & 0.38 \\
\hline Genotypes & 3 & $50.2^{* *}$ & $158^{* *}$ & $24.1^{* *}$ & $21.5 * *$ & $21.9 * *$ & $5.49^{*}$ \\
\hline Error A & 6 & 7.81 & 3.30 & 2.44 & 0.579 & 0.35 & 0.90 \\
\hline Sodium azide & 3 & $62.5 * *$ & 12.46 & $7.03 * *$ & $3.28^{* *}$ & 0.35 & $3.45 *$ \\
\hline G $\times$ S & 9 & $7.2^{*}$ & $29.6^{*}$ & 0.46 & $2.25 * *$ & 0.32 & 2.34 \\
\hline Error B & 23 & 3.25 & 9.13 & 1.65 & 0.33 & 0.24 & 1.24 \\
\hline
\end{tabular}

****Significant at 0.05 and 0.01 of levels probability, respectively

No. of fertile spikelets / spike, No. of spikes / plant, straw yield / plant and biological yield/plant.

The mean of square for interaction between genotypes and sodium azide showed significant for all genotypes differed in their performance under various levels of sodium azide. These results are harmony with those obtained by Ahmad et al., (2018)

\section{Mean performance of $M_{2}$ generation as influenced by sodium azide}

The results presented in Tables (5, 6 and 7) show mean performance of days to heading. it is obvious that all values of days to $50 \%$ heading varied from 84.495 days (Sids-12) to 92.74 days (Sahel-1), while the effect of sodium azide treatments decrease in this trait was observed due to $0.08 \%$ treatments with value of (84.82), $0.06 \%$ treatment with value (87.74) and control with value (88.32) less than $0.04 \%$ (90.41). Mean performance for plant height among four bread wheat genotypes. Gemmeiza-11 produced the tallest height $(91.02 \mathrm{~cm}$.) otherwise Sids-12 was the shortest height $(83.15 \mathrm{~cm}$.). while the effects sodium azide treatments it varied $86.62 \mathrm{~cm} ;(0.06 \%)$, $87.79 \mathrm{~cm}(0.08 \%)$ and $88.46(0.04 \%)$ it less than control $88.99 \mathrm{~cm}$; for plant height $/ \mathrm{cm}$;. peduncle

Length is very important for selecting high yield. The data show the mean performance for peduncle length it varied from $35.57 \mathrm{~cm}$., (Sids-12) to 


\begin{tabular}{|c|c|c|c|c|c|c|c|}
\hline 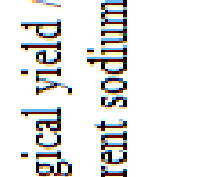 & 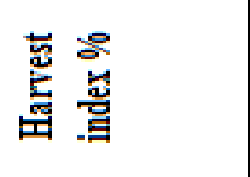 & $\stackrel{\infty}{+}$ & है & $\stackrel{\mathscr{2}}{\rightleftharpoons}$ & 용 & 䄯 & 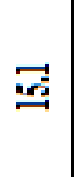 \\
\hline 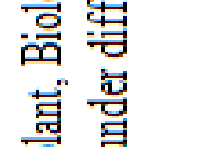 & 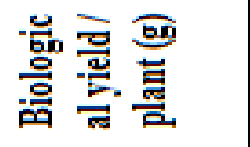 & 궁 & $\frac{2}{6}$ & 릉 & E & 莡 & $\mathscr{\rho}$ \\
\hline 壳总 & 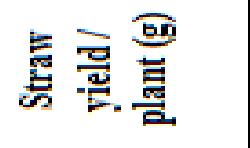 & $\stackrel{2}{\circ}$ & 象 & 突 & 농 & 疍 & 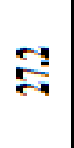 \\
\hline 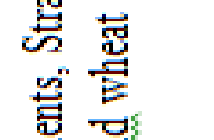 & 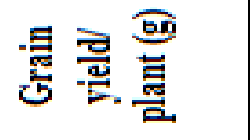 & $\Sigma$ & $\stackrel{\text { 表 }}{\Rightarrow}$ & $\stackrel{8}{3}$ & $\stackrel{\hbar}{\Rightarrow}$ & ㅎㅇ & 胥 \\
\hline 合司言 & 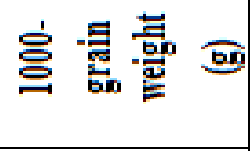 & 8 & 考 & ప్ & $\begin{array}{l}\sqrt[3]{9} \\
\frac{5}{9}\end{array}$ & g & 옹 \\
\hline 昰 & 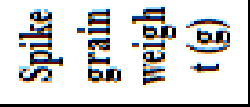 & $\stackrel{9}{8}$ & 袭 & ్ㅗㅇ & 웡 & gㅇㅇㅇ & 寻 \\
\hline 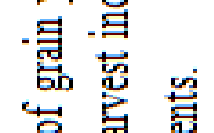 & 它罢尝 & $\underset{7}{2}$ & 表 & 突 & ๙ి & 电 & हृ \\
\hline 旁品罠 & 它氮荳 & E & 㐘 & 격 & 尝 & 落 & 象 \\
\hline 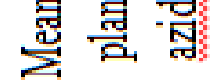 & 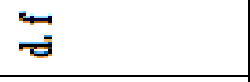 & $\rightarrow$ & $m$ & $\infty$ & $\infty$ & $a$ & $\nexists$ \\
\hline$\vec{a}$ & $i$ & 愙 & 空 & 葍 & 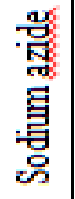 & $\underset{x}{\infty}$ & 窝 \\
\hline
\end{tabular}


Table (5): Mean performance of days to heading and plant height for Gemmeiza-11, Shandawel-1, Sids-12 and Sahel-1 by sodium azide treatments and their interaction in $\mathbf{M}_{2}$ generation under water steers.

\begin{tabular}{|c|c|c|c|c|c|c|c|c|c|c|}
\hline \multirow[t]{2}{*}{ Treatments } & \multicolumn{4}{|c|}{ Days to heading $50 \%$} & \multirow[t]{2}{*}{ Mean } & \multicolumn{4}{|c|}{ Plant height $(\mathrm{cm})$} & \multirow[t]{2}{*}{ Mean } \\
\hline & Control & $\begin{array}{l}0.04 \\
\%\end{array}$ & $\begin{array}{l}0.06 \\
\%\end{array}$ & $\begin{array}{l}0.08 \\
\%\end{array}$ & & Control & $\begin{array}{l}0.04 \\
\%\end{array}$ & $\begin{array}{l}0.06 \\
\%\end{array}$ & $\begin{array}{l}0.08 \\
\%\end{array}$ & \\
\hline Gemmieza-11 & 86.66 & 87 & 86 & 82.33 & 85.49 & 90.66 & 92.63 & 87.75 & 93.06 & 91.03 \\
\hline Sids-12 & 83.66 & 87.33 & 84.33 & 82.66 & 88.57 & 83.4 & 82.16 & 84.4 & 82.66 & 87.17 \\
\hline Shandawel-l & 87.66 & 91.66 & 89.33 & 85.66 & 84.49 & 92.3 & 83.83 & 84.36 & 88.26 & 83.16 \\
\hline Sahel-1 & 95.33 & 95.66 & 91.33 & 88.66 & 92.74 & 89.6 & 95.23 & 90 & 87.2 & 90.51 \\
\hline Mean & 88.32 & 90.41 & 87.74 & 84.82 & & 88.99 & 88.46 & 86.62 & 87.79 & \\
\hline \multicolumn{11}{|l|}{ L.S.D } \\
\hline G & \multicolumn{4}{|c|}{2.792} & \multicolumn{6}{|c|}{1.817} \\
\hline $\mathrm{Sa}$ & \multicolumn{4}{|c|}{1.519} & \multicolumn{6}{|c|}{2.546} \\
\hline $\mathrm{G} \times \mathrm{Sa}$ & \multicolumn{4}{|c|}{3.038} & \multicolumn{6}{|c|}{5.092} \\
\hline
\end{tabular}

Table (6): Mean performance peduncle length and number of tillers/plant for Gemmeiza-11, Shandawel-1, Sids-12 and Sahel-1 by sodium azide treatments and their interaction in $\mathrm{M}_{2}$ generation under water steers.

\begin{tabular}{|c|c|c|c|c|c|c|c|c|}
\hline \multirow[t]{2}{*}{ Treatments } & \multicolumn{2}{|c|}{ Peduncle length $(\mathrm{cm})$} & \multirow{2}{*}{\begin{tabular}{|l|} 
Mean \\
\end{tabular}} & \multicolumn{4}{|c|}{ Number of tillers/plant } & \multirow[t]{2}{*}{ Mean } \\
\hline & Control & $0.04 \% \quad 0.06 \% \quad 0.08 \%$ & & Contro & $0.04 \%$ & $0.06 \%$ & $0.08 \%$ & \\
\hline $\begin{array}{l}\text { Gemmieza- } \\
\text { ll }\end{array}$ & 38.39 & $\begin{array}{lll}38.36 & 38.45 \quad 39.61\end{array}$ & 38.70 & 6.16 & 5.96 & 5.61 & 5.35 & 5.77 \\
\hline & 35.64 & $34.68 \quad 35.4 \quad 36.56$ & 35.57 & 4.4 & 5.43 & 5.7 & 5.06 & 5.14 \\
\hline Shandawel-1 & 36.76 & $\begin{array}{lll}35.28 & 36.51 & 36.97\end{array}$ & 36.38 & 8.1 & 8.8 & 6.56 & 7.55 & 7.75 \\
\hline Sahel-1 & 35.88 & $34.93 \quad 35.25 \quad 37.45$ & 35.87 & 9.66 & 7.9 & 6.66 & 6.66 & 7.72 \\
\hline Mean & 36.66 & $\begin{array}{lll}5.81 & 36.40 & 37.64\end{array}$ & & 7.08 & 7.02 & 6.13 & 6.15 & \\
\hline \multicolumn{9}{|l|}{ LS.D } \\
\hline $\mathrm{G}$ & & 1.560 & & & 0.7 & & & \\
\hline $\mathrm{Sa}$ & & 1.082 & & & 0.4 & & & \\
\hline $\mathrm{G} \times \mathrm{Sa}_{2}$ & & 2.164 & & & & & & \\
\hline
\end{tabular}


Table (7): Mean performance spike length and number of spikelets/spike for Gemmeiza-11, Shandawel-1, Sids-12 and Sahel-1 by sodium azide treatments and their interaction in $\mathrm{M}_{2}$ generation under water steers.

\begin{tabular}{|c|c|c|c|c|c|c|c|c|c|c|}
\hline \multirow[t]{2}{*}{ Treatments } & \multicolumn{4}{|c|}{ Spike length/cm } & \multirow[t]{2}{*}{ Mean } & \multicolumn{4}{|c|}{ Number of spikelets/spike } & \multirow[t]{2}{*}{ Mean } \\
\hline & Control & $\begin{array}{l}0.04 \\
\% \\
\end{array}$ & $0.06 \%$ & $0.08 \%$ & & Control & $\begin{array}{l}0.04 \\
\%\end{array}$ & $0.06 \%$ & $0.08 \%$ & \\
\hline Gemmeiza-11 & 15.04 & 15.21 & 14.95 & 15.18 & 15.09 & 21.86 & 24.06 & 22.1 & 23.1 & 22.78 \\
\hline Sids-12 & 12.8 & 11.83 & 12.57 & 13.25 & 12.61 & 22 & 21.4 & 22.26 & 21.53 & 21.79 \\
\hline Shandawel-1 & 13.2 & 12.91 & 13.21 & 13.13 & 13.11 & 24.06 & 24.06 & 21.86 & 23.1 & 23.27 \\
\hline Sahel-1 & 12.28 & 11.86 & 12.02 & 11.7 & 11.96 & 22.93 & 22.93 & 21.66 & 20.65 & 22.04 \\
\hline Mean & 13,33 & 12.95 & 13.18 & 13.31 & & 22.71 & 23.11 & 21.97 & 22.09 & \\
\hline \multicolumn{11}{|l|}{ L.S.D } \\
\hline G & \multicolumn{4}{|c|}{0.597} & \multicolumn{6}{|c|}{0.951} \\
\hline Sa & \multicolumn{4}{|c|}{0.416} & \multicolumn{6}{|c|}{0.941} \\
\hline $\mathrm{G} \times \mathrm{Sa}$ & \multicolumn{4}{|c|}{0.832} & \multicolumn{6}{|c|}{1.882} \\
\hline
\end{tabular}

$38.70 \mathrm{~cm}$. , (Gemmieza-11). Regarding effect of sodium azide treatments it changed from $35.81 \mathrm{~cm} .,(0.04 \%)$ to $37.64 \mathrm{~cm} ;(0.08 \%)$ but $(0.06 \%)$ and control are between them. Regarding mean performance for No. of tillers/plant, it changed from 5.14 (Sids-12) to 7.75 (Shandaweel-1). Regarding sodium azide effects treatments exhibited the higher values of 7.08 and 7.02 control and $0.04 \%$ respectively. But the $0.06 \%$ treatment give the lowest value for 6.13 no. of tillers /plant. Spike length it varied from $11.965 \mathrm{~cm}$; (Sahel-1) to 15.095 $\mathrm{cm}$; (Gemmeiza-11), while the effect of sodium azide treatments decrease in this trait was observed due to $0.04 \%$ treatments with value of $(12.95 \mathrm{~cm}$.), 0.06 $\%$ treatment with value $(13.18 \mathrm{~cm}$.) and $0.08 \%$ with value $(13.31)$, its less than control (13.33). Concerning mean performance showed significant differences among four bread wheat genotypes. Shandweel-1 produced the heights value (23.27) otherwise Sids-12 was the lowest value (21.79). While the effects sodium azide treatments it varied $21.97(0.06 \%)$, to $23.11(0.04 \%)$ for No. of spikeletslspike.

The data in Tables (8, 9 and 10) showed that mean performance for no. of infertile spikeletslspike in four wheat genotypes in $\mathrm{M}_{2}$ generation it varied from 1.74 (sahel-1) to 2.99 (shandaweel-1). Regarding effect of sodium azide treatments it changed from 1.84 (control) to $2.38(0.04 \%)$ for this trait under water stress. Regarding mean performance for no. of fertile spikelets $\backslash$ spike as 
Table (8): Mean performance for number of infertile spikelets/spike for Gemmeiza-11, Shandawel-1, Sids-12 and Sahel-1 by sodium azide treatments and their interaction in $\mathrm{M}_{2}$ generation under water steers.

\begin{tabular}{|c|c|c|c|c|c|c|c|c|c|c|}
\hline \multirow[t]{2}{*}{ Treatments } & \multicolumn{4}{|c|}{ Number of infertile spikelets/spike } & \multirow[t]{2}{*}{ Mean } & \multicolumn{4}{|c|}{ Number spikes/plant } & \multirow[t]{2}{*}{ Mean } \\
\hline & Control & $\begin{array}{l}0.04 \\
\%\end{array}$ & $\begin{array}{l}0.06 \\
\% \\
\end{array}$ & $\begin{array}{l}0.08 \\
\%\end{array}$ & & Control & $\begin{array}{c}0.04 \\
\%\end{array}$ & $\begin{array}{l}0.06 \\
\%\end{array}$ & $\begin{array}{l}0.08 \\
\%\end{array}$ & \\
\hline Gemmieza-11 & 1.266 & 2.233 & 1.55 & 2.066 & 1.77 & 5.28 & 4.93 & 4.8 & 4.6 & 4.90 \\
\hline Sids-12 & 1.466 & 2.1 & 2.233 & 2.166 & 1.99 & 4.33 & 5.16 & 5.06 & 4.46 & 4.75 \\
\hline Shandawel-l & 2.866 & 3.366 & 2.966 & 2.8 & 2.99 & 6.46 & 5.4 & 6.16 & 6.30 & 6.08 \\
\hline Sahel-1 & 1.8 & 1.833 & 1.966 & 1.4 & 1.74 & 8.8 & 6.4 & 5.33 & 5.4 & 6.48 \\
\hline Mean & 1.84 & 2.38 & 2.17 & 2.10 & & 6.21 & 5.47 & 5.33 & 5.19 & \\
\hline \multicolumn{11}{|l|}{ L.S.D } \\
\hline G & \multicolumn{4}{|c|}{0.697} & \multicolumn{6}{|c|}{1.136} \\
\hline $\mathrm{Sa}$ & \multicolumn{4}{|c|}{0.306} & \multicolumn{6}{|c|}{0.697} \\
\hline $\mathrm{G} \times \mathrm{Sa}$ & \multicolumn{4}{|c|}{0.873} & \multicolumn{6}{|c|}{1.395} \\
\hline
\end{tabular}

Table (9): Mean performance for number of grains/spike and spike grain weight of Gemmeiza-11, Shandawel-1, Sids-12 and Sahel-1 by sodium azide treatments and their interaction in $\mathrm{M}_{2}$ generation under water steers.

\begin{tabular}{|c|c|c|c|c|c|c|c|c|c|c|}
\hline \multirow[t]{2}{*}{ Treatments } & \multicolumn{4}{|c|}{ Number of grain/spike } & \multirow[t]{2}{*}{ Mean } & \multicolumn{4}{|c|}{ Spike grain weight(g) } & \multirow[t]{2}{*}{ Mean } \\
\hline & Control & $\begin{array}{c}0.04 \\
\%\end{array}$ & $\begin{array}{c}0.06 \\
\%\end{array}$ & $\begin{array}{c}0.08 \\
\%\end{array}$ & & Control & $\begin{array}{c}0.04 \\
\%\end{array}$ & $\begin{array}{c}0.06 \\
\%\end{array}$ & $\begin{array}{c}0.08 \\
\%\end{array}$ & \\
\hline Gemmieza-11 & 73.08 & 71.93 & 68.4 & 68.05 & 70.36 & 3.76 & 4.13 & 3.71 & 3.9 & 3.87 \\
\hline Sids-12 & 84.7 & 73.66 & 75.1 & 82.26 & 78.93 & 3.99 & 3.48 & 3.28 & 3.68 & 3.61 \\
\hline Shandawel-l & 70.1 & 64.03 & 65.43 & 68.2 & 66.94 & 3.36 & 3.08 & 2.74 & 3.30 & 3.12 \\
\hline Sahel-1 & 61.8 & 66.06 & 61.63 & 55.6 & 61.27 & 3.05 & 3.06 & 2.68 & 2.78 & 2.89 \\
\hline Mean & 72.42 & 68.92 & 67.64 & 68.52 & & 3.54 & 3.43 & 3.10 & 3.41 & \\
\hline \multicolumn{11}{|l|}{ L.S.D } \\
\hline G & \multicolumn{4}{|c|}{9.926} & \multicolumn{6}{|c|}{0.489} \\
\hline $\mathrm{Sa}$ & \multicolumn{4}{|c|}{4.644} & \multicolumn{6}{|c|}{0.279} \\
\hline $\mathrm{G} \times \mathrm{Sa}$ & \multicolumn{4}{|c|}{12.732} & \multicolumn{6}{|c|}{0.686} \\
\hline
\end{tabular}


Table (10): Mean performance for 1000- grain weight and grain yield/plant of Gemmeiza-11, Shandawel-1, Sids-12 and Sahel-1 by sodium azide treatments and their interaction in $\mathrm{M}_{2}$ generation under water steers.

\begin{tabular}{|c|c|c|c|c|c|c|c|c|c|c|}
\hline \multirow[t]{2}{*}{ Treatments } & \multicolumn{4}{|c|}{ 1000-Grain weight } & Mean & \multicolumn{4}{|c|}{ Grain yield/plant (g) } & \multirow[t]{2}{*}{ Mean } \\
\hline & Control & $\begin{array}{c}0.04 \\
\%\end{array}$ & $\begin{array}{c}0.06 \\
\%\end{array}$ & $\begin{array}{c}0.08 \\
\%\end{array}$ & & Control & $\begin{array}{c}0.04 \\
\%\end{array}$ & $\begin{array}{c}0.06 \\
\%\end{array}$ & $\begin{array}{c}0.08 \\
\%\end{array}$ & \\
\hline Gemmieza-11 & 51.44 & 57.7 & 54.12 & 57.30 & 55.14 & 16.51 & 17.04 & 15.82 & 12.45 & 16.12 \\
\hline Sids-12 & 46.98 & 47.33 & 44.1 & 44.99 & 45.85 & 14.86 & 14.08 & 15.01 & 14.82 & 14.69 \\
\hline Shandawel-1 & 48.07 & 48.10 & 41.96 & 48.33 & 46.61 & 19.4 & 13.84 & 14.76 & 17.12 & 16.28 \\
\hline Sahel-1 & 49.43 & 46.36 & 43.75 & 50.58 & 47.53 & 19.49 & 13.84 & 14.8 & 16.95 & 16.27 \\
\hline Mean & 48.98 & 49.87 & 45.98 & 50,3 & & 18.23 & 14.7 & 15.09 & 15.33 & \\
\hline \multicolumn{11}{|l|}{ L.S.D } \\
\hline G & \multicolumn{4}{|c|}{2.983} & \multicolumn{6}{|c|}{4.629} \\
\hline Sa & \multicolumn{4}{|c|}{3.809} & \multicolumn{6}{|c|}{2.187} \\
\hline $\mathrm{G} \times \mathrm{Sa}$ & \multicolumn{4}{|c|}{7.227} & \multicolumn{6}{|c|}{5.960} \\
\hline
\end{tabular}

influenced by sodium azide on $\mathrm{M}_{2}$ generation in four wheat verities under water stress, Gemmeiza-11 give heights value 21.002, but Sids-12 give lowest fertile spikeletslspike (19.80). Regarding sodium azide effects treatments exhibited the higher values of 20.86 and 20.73 (control and $0.04 \%$ respectively). But the $0.06 \%$ treatment give lowest value (19.79). Mean performance for yield and its components ubjected wheat varieties to sodium azide doses resulted in significant variation for No. of spikes/plant, Spike grain weight/gm. and No. of grains/pike, but non-significant for grain yield ।plant in all cases revealing the great influence of the sodium azide doses on genetic makeup of wheat varieties. Wheat cultivar Sahel-1 produced the greatest number of spikes / plant (6.48), whereas Sids-12 was the lowest (4.75) for no. of spikes / plant. Regarding mean effect of sodium azide treatments it varied from 5.19 (0.08\%) to 6.21 (control), for this trait. Sids-12 produced highest no. of grain /spike (78.93 grain) but the Sahel-1 cultivar was give lowest no. of grainlspike (61.27 grain). While effect of sodium azide doses it varied from 67.64 grain under using $(0.06 \%)$ sodium azide, 68.52 grain $(0.08 \%)$ and 68.92 grain $(0.04 \%)$, were less than (control) 72.42 no. of grainlspike. Spike grain weight mean performance changed from 2.897 (g) (Sahel-1) to 3.87 (Gemmeiza-11). Meanwhile, mean effects of sodium azide treatment for this trait it ranged from $3.10(0.06 \%)$ to 3.54 (control) under water stress. Regarding mean performance for 1000-grain 
weight, the Gemmeiza-11 produced heights weight for 1000-grain (55.14 g.) whereas Sids-12 lowest for 1000-grain weight (45.85 g.) while mean effect of sodium azide the treatments $49.87(\mathrm{~g})(0.04 \%)$ and $50.3(\mathrm{~g})(0.08 \%)$ were more than (control and 0.04\%) 48.98gm; and 45.98 (g) respectively. Mean performance for grain yield $\backslash$ plant (g.) it changed from 14.69 (g) (Sids-12) to 16.28 (g) (Shandaweel-1). Regarding mean effects of sodium azide doses it ranged from $14.7 \mathrm{gm} ;(0.04 \%)$ to $18.23 \mathrm{gm}$; (control).

\section{Genetic correlation in $M_{2}$ generation as influenced by sodium azide:-}

Results presented in Table (11) show genetic correlation in $\mathrm{M}_{2}$ generation and their parents as influenced by sodium azide. The results demonstrated significantly $(\mathrm{P} \leq 0.05)$ positive association between some pairs of traits. Days to $50 \%$ heading showed positive and significant correlation with each of number of tillers/plant $\left(0.87^{* *}\right)$ and number of spikes/plant. Moreover, plant height demonstrated positive and highly significant association with harvest index \% $\left(0.66^{* *}\right)$, grain yield/plant $\left(0.69^{* *}\right)$ and with 1000 - grain weight $\left(0.57^{*}\right)$. These results are in agreement with Dabi et. al., (2016)

The trait peduncle length exhibited significantly positive correlation with spike length $\left(0.96^{* *}\right)$, spike grain weight $\left(0.66^{* *}\right), 1000$-grain weight $\left(0.96^{* *}\right)$ and harvest index $\%\left(0.96^{* *}\right)$. Whereas spike length revealed positive and significant correlations with spike grain weight $\left(0.74^{* *}\right), 1000$-grain weight $\left(0.82^{* *}\right)$ and harvest index $\%\left(0.60^{*}\right)$. Therefore increasing led to an increase in spike grain wheat, 1000-grain weight and harvest index $\%$. These results are in Ganno et. al., (2017) and Ahmad et al., (2018).

The trait number of tillers/plant indicated significantly positive association with number of spikes/plant $\left(0.906^{* *}\right)$, spikelets/ spike $\left(0.69^{* *}\right)$, straw yield/plant $\left(0.52^{*}\right)$, biological yield/plant $\left(0.55^{*}\right)$ and grain yield/plant $\left(0.58^{*}\right)$. Also number of spikes/plant established positive and significant correlations with straw yield/plant $\left(0.68^{* *}\right)$, biological yield/plant $\left(0.69^{* *}\right)$, and grain yield/plant $(0.64 * *)$. These findings a comprehensive selection for these traits will ultimately indirect improve grain yield in bread wheat genotypes under sodium azide. These results are in agreement with Mangi et. al., (2016).

Moreover, number of spikelets/spike showed also positive and significant correlation with grain yield/plant $(0.54 *)$. Meanwhile, trait spike grain weight indicated a positive and significant correlation with both 1000-grain weight $\left(0.66^{* *}\right)$ and number of grains/spike $\left(0.74^{* *}\right)$. Demonstrating a comprehensive selection for these traits will ultimately improve spike grain weight in bread wheat genotypes. Mangi et. al., (2016) and Ayer et. al., (2017). 


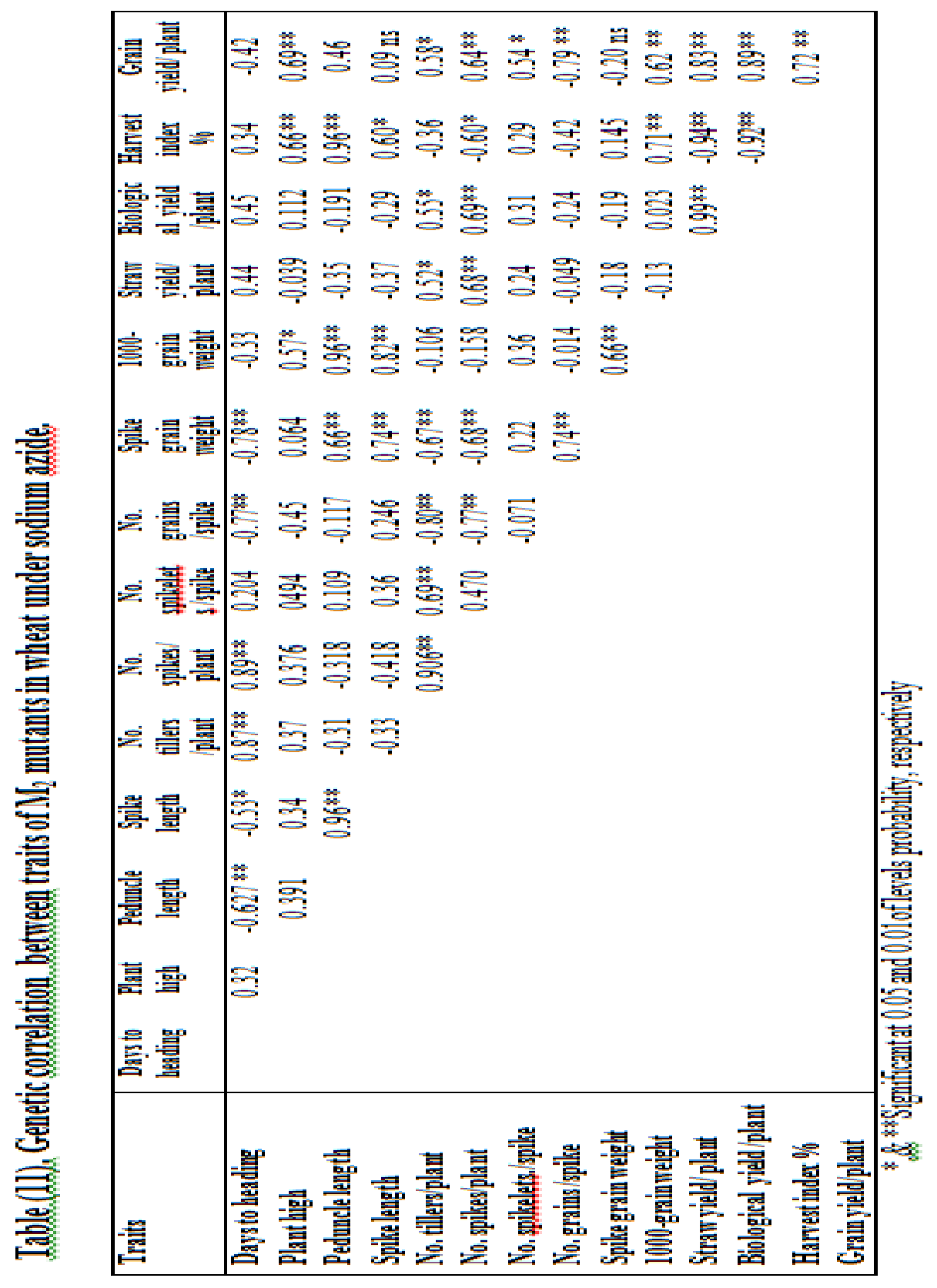


The results demonstrated significantly $(\mathrm{P} \leq 0.05)$ positive association between various traits, such as 1000-grain weight positive and significant correlation with both harvest index $\%(0.71 * *)$ and grain yield /plant $(0.62 * *)$. The character straw yield/plant demonstrated positive and highly significant association with biological yield/plant $(0.99 * *)$ and grain yield/plant $\left(0.83^{* *}\right)$. Meanwhile, positive and highly significant association was registered between grain yield/plant and biological yield/plant valued (0.89). The character harvest index demonstrated positive and highly significant association with grain yield/plant $(0.72 * *)$. Hereby a comprehensive selection for these traits will ultimately improve grain yield in bread wheat genotypes. These results are in Mangi et. al., (2016), how reported that positive and significant association spike length demonstrated with grain yield $\left(0.852^{*}\right)$. spikelets /spike exhibited significantly positive correlation with grain yield $(0.872 *)$, whereas grains / spike also positive and significant correlations with grain yield $\left(0.825^{*}\right)$ and grains weight spike $\left(0.902^{*}\right)$. $\left(0.896^{*}\right)$, spikelets / spike $\left(0.849^{*}\right)$, seed index $\left(0.855^{*}\right)$ and grains weight / spike $\left(0.961^{*}\right) .\left(0.888^{*}\right)$. Moreover, there was also a positive and significant correlation $(0.947 * *)$ between harvest index and grain yield characters spike length, spikelets spike, grains spike.

Conclusively, genetic correlation coefficient represents the degree to which respective traits are correlated therefore correlation coefficient have predictive value in selection for water stress.

\section{REFERENCE}

Ahmad, T., Kumar, A., Pandey, D., and Prasad, B. (2018). Correlation and path coefficient analysis for yield and its attributing traits in bread wheat (Triticum aestivum L. em Thell). Journal of Applied and Natural Science, 10(4), 1078-1084.

Ayer, D. K., Sharma, A., Ojha, B. R., Paudel, A., and Dhakal, K. (2017). Correlation and path coefficient analysis in advanced wheat genotypes. SAARC Journal of Agriculture, 15(1), 1-12.

Bano S., Z. A. Soomro, A. A. Kaleri, Rabab Akram, Sajida Nazeer ,A. Laghari, I A. Chandio, R. Keerio and N. A. Wahocho (2017) Evaluation of $\mathrm{M}_{2}$ wheat (Triticum aestivum $\mathrm{L}$.) mutants for yield and its contributing traits. Journal of Basic \& Applied Sciences, (13): 359-362.

Baye A., B. Berihun, M. Bantayehu and B. Derebe (2020). Genotypic and phenotypic correlation and path coefficient analysis for yield and yieldrelated traits in advanced bread wheat (Triticum aestivum L.) lines. Soil \& Crop Sciences | Research Article, (6): 1-17. 
Bhutto L.A, Soomro Z.A, Ansari B.A, Jarwar A.R. And B.H. Jalbani (2005). Estimation of phenotypic correlation between grain yield and Its main components in brassica species. Indus J of P Sci; 3(4): 327-331.

Cattivelli, L., F. Rizza, F.W. Badeck, E. Mazzucotelli,A.M. Mastrangelo, E. Francia, C. Mare., A. Tondelliand A.M. Stanca, (2008). Drought tolerance improvement in crop plants: An integrated view from breeding to genomics. Field Crop Res., (105): 1-4.

Dabi, A., Mekbib F. and T. Desalegn (2016). Estimation of genetic and phenotypic correlation coefficients and path analysis of yield and yield contributing traits of bread wheat (Triticum aestivum L.) genotypes. International Journal Natural Resource Ecology Management, 1(4): $145-154$.

Ganno, J., Alemu, D. and G. Ayalew (2017). Study of genetic variation and grain quality traits in bread wheat (Tritium aestivum L.) genotypes. African Journal of Plant Breeding, 4(1): 172-182.

Khan, A. A., Alam, M. A., Alam, M. K., Alam, M. J., and Z. I. Sarker (2013). Correlation and path analysis of durum wheat (Triticum turgidum L. var. Durum). Bangladesh Journal of Agricultural

Maluszynski M., Beant S . Ahloowalia and B. Sigurbjornsson (1995) Application of in vivo and in vitro mutation techniques for crop improvement. Euphytica, (85): 303 -315.

Mangi, N., Baloch, A.W., Arain, S.M., Baloch, M., Kandhro, M.N., Abro, T.F., Baloch, S.N. and S.N. Mari (2016). Evaluation of advance mutant genotypes and interrelationship analysis of yield and yield associated traits in bread wheatgenotypes. Sindh University Research Journal (Science Series), 48 (3): 783-786.

Mohammad T, Amin M, Subhan FE, Khan N.I. and A.J. Khan ( 2008). Identification of traits in bread wheat genotypes (Triticum aestivum L.) contributing to grain yield through correlation and path coefficient analysis. Pak J Bot; 40(6): 2393-2402.

Singh, P. and Narayanan (2000). Biometrical Techniques in Plant Breeding. Kalyani Publishers, New Delhi, India.

Steel, R.G. D and J.H. Torrie and D.H. Dickey (1997). Principles and producers of statistics a. Biometrical Approach $3^{\text {rd }}$ Ed,Mc Graw Hill, New York.

Wannajindaporn, A., Poolsawat, O., Chaowiset, W. and Tantasawat, P.A. (2014). Evaluation of genetic variability in in vitro sodium azide-induced Dendrobium 'Earsakul' mutants. Genetics and Molecular Research, (13): 5333-5342.

Wen J. G and H.G. Liang (1995) Effects of KCN and NaN3 pretreatment on the cyanide resistant respiration in tabacco callus. Acta. Botanica. Sinice, (37): 711-717. 


\title{
تحليل الارتباط الوراثي بين بعض الصفات في الجيل الثاني الطفري لقمح القاجي

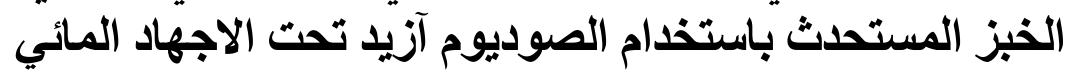

\author{
رجب فتحي ندا 1 ـالسبد السيد حسن 1 ,علي عبدالحميد حسان 1 ركريا محمد علي عطية2

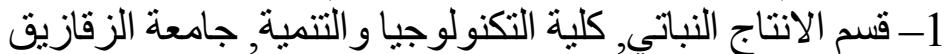

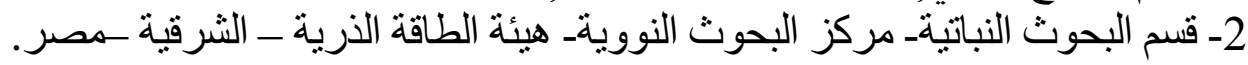

أُجري هذا البحث بالمزرعة التجريبية بكلية التكنولوجيا و التنمية جامعة الزقازيق

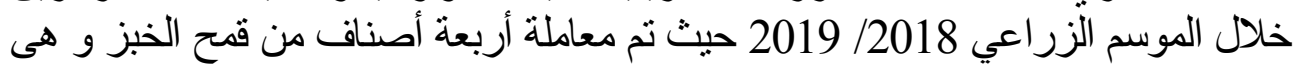

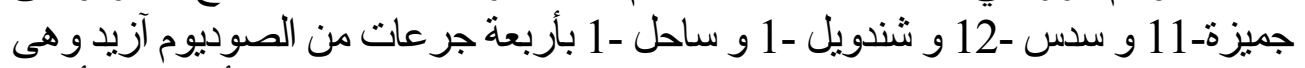

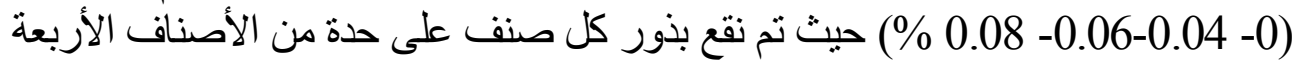

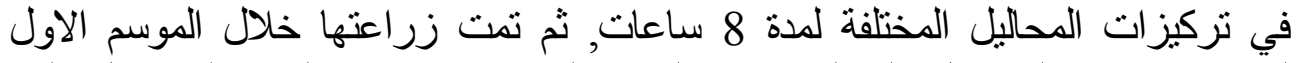

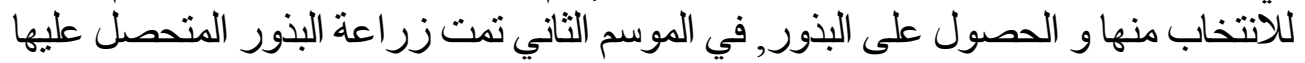

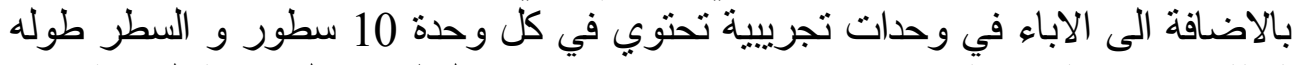

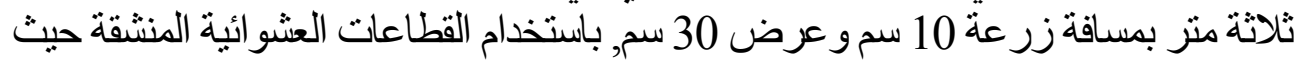

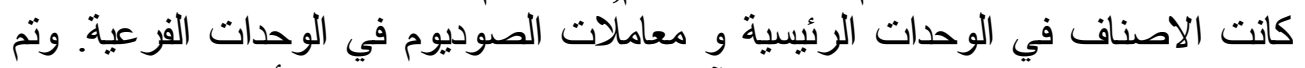

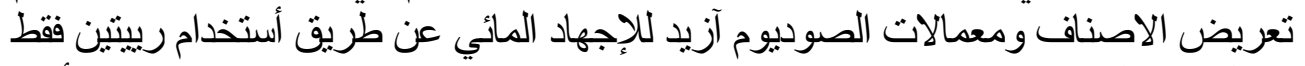

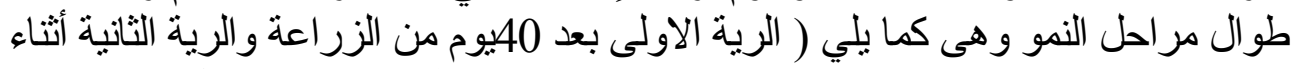

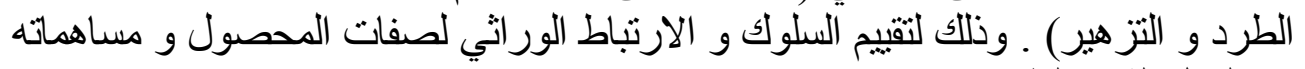
في الجيل الثاني الطفري.

وكَاتت أهم النتائج المتحصل عليهانيا كما يلي : أظهر تحليل التباين اختلافات معنوية و عالية

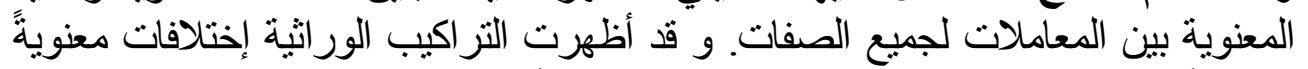

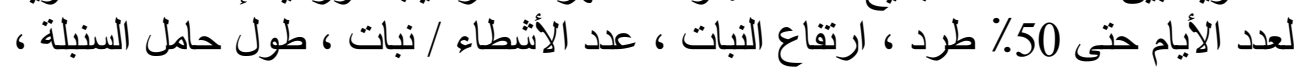

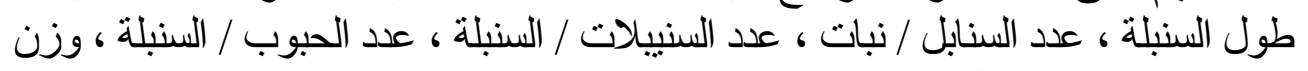

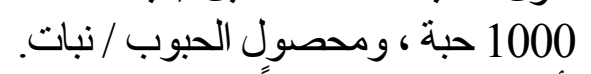

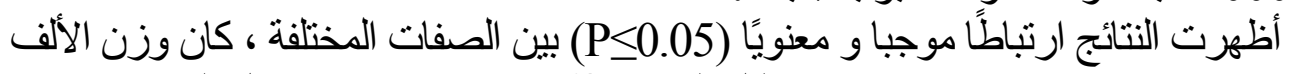

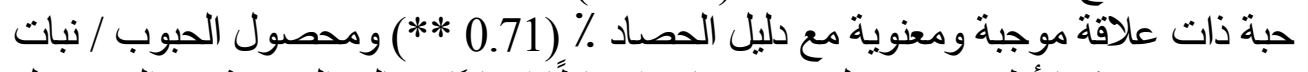

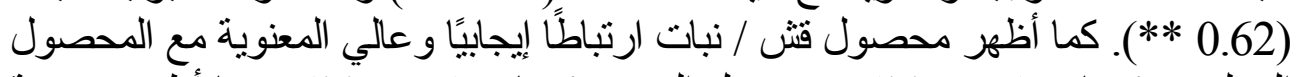

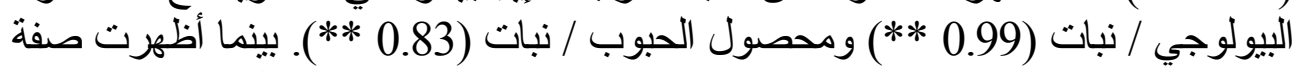

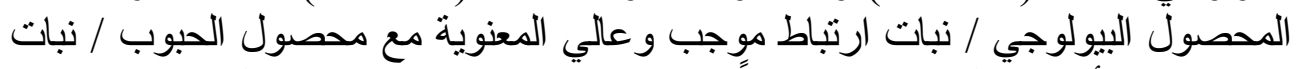

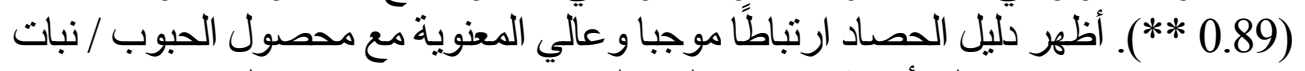

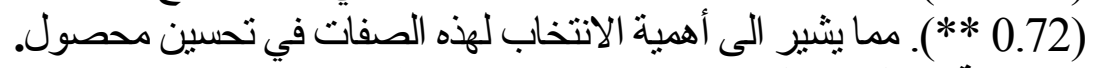

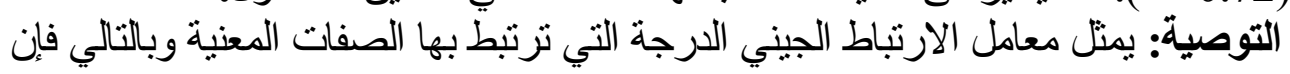

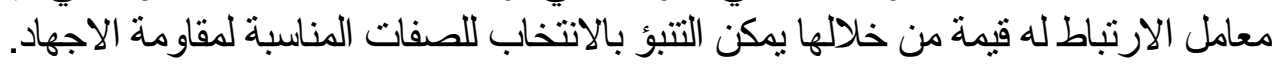

